for example, has heard of Coyotes hunting in pairs, one animal driving the game toward another Coyote lying in wait. The deliberate attempt to hold attention of prey or to lure it within range as described above is especially interesting in view of its indirectness. Coyotes have several times been recorded working in pairs, one attracting the attention of the prey by performing antics like those reported above, while another sneaks up unnoticed. J. F. Dobie (1949. The Voice of the Coyote) cites good examples of this: ". . . noticed a coyote silently jumping up and around. Then he saw a second coyote off some distance slinking slowly and carefully forward. Between the two a sitting jack rabbit appeared to be fascinated by the didos of the first coyote and to be unaware of the approach of the other..." In another case he recounts how coyotes caught some pelicans, one coyote attracting their attention by catching up bits of wood and throwing them into the air, chasing her tail, crouching and making sudden springs into the air." Even a Sandhill Crane was caught in this way by another couple of coyotes, one of which was turning somersaults and running round and round. This behavior of a wild species has close similarity to an old method of luring ducks called "tolling" and much favoured in Europe. The same method is being used at present with great success at the Delta Waterfowl Research Station (Delta, Manitoba). A well-trained dog is directed by his concealed trainer to go through a complicated series of maneuvers, performing play-like movements in full sight of a flock of wild ducks. The latter are strangely attracted by the antics of the dog and are thereby lured into a trap. Thousands of ducks have been trapped and banded at Delta by this means.

\title{
Gray Squirrel (Sciurus carolinensis) in Sask.
}

By Robert W. Nero, Saskatchewan Museum of Natural History

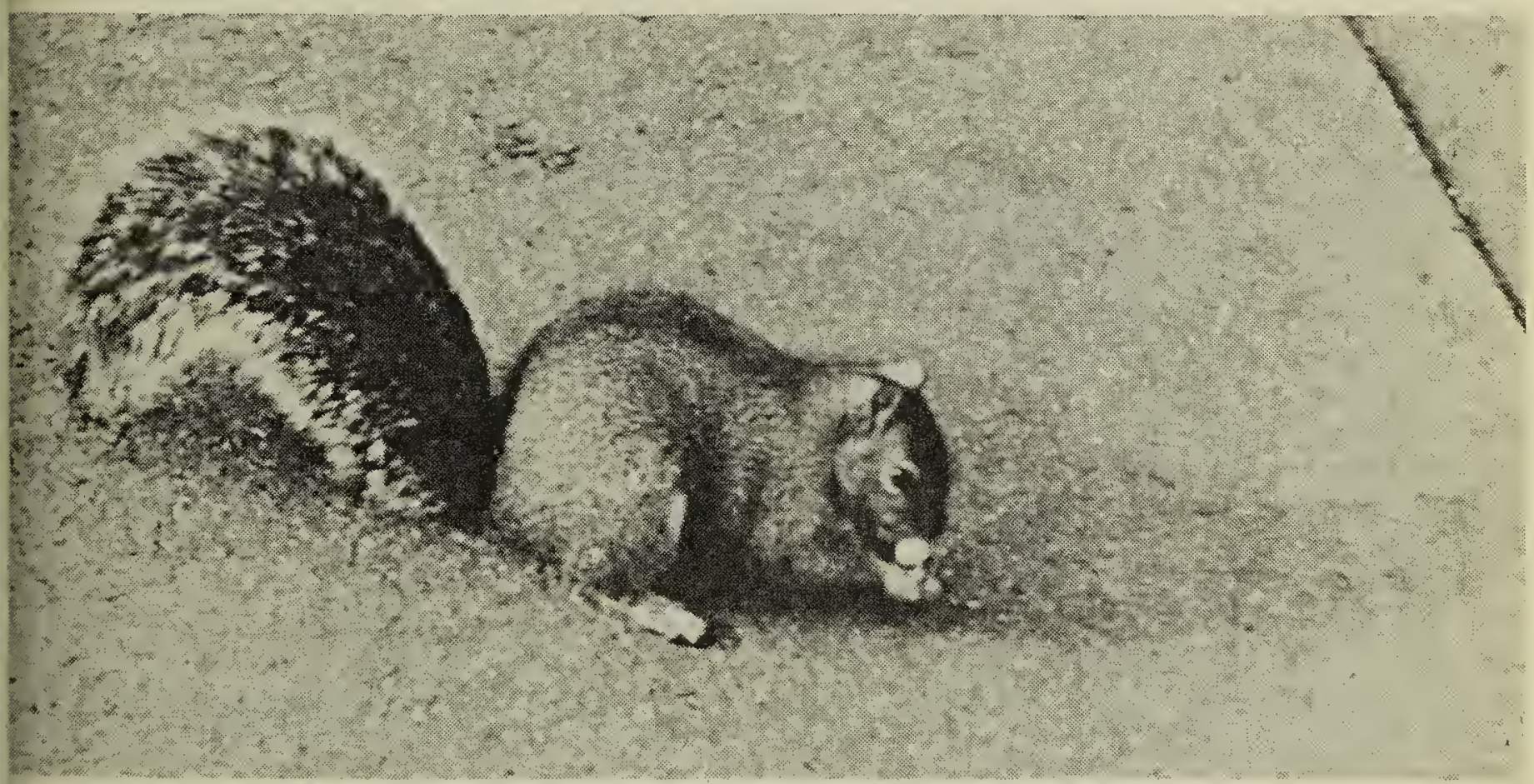

Photo trom a kodachrome by Iohn Bergsteinsson

Gray Squirrel feeding on a Saskatoon sidewalk.

The occurrence of the Gray Squirrel (Sciurus carolinensis) some 70 miles north of Regina is unexpected considering its known range and habits, and it seeems likely that it has been introduced into this area." It is known to occur normally in southeastern Manitoba west to Ninette according to R. W. Sutton (pers. commun.) but it is rare and only locally distributed in this area. In the United States it is found as far west as eastern North Dakota. There are a $1 \mathrm{so}$ isolated occurrences in north-central North Dakota along the bottom of the loop of the Souris River (Mouse River in the U.S.) which probably represent introductions (Hibbard, 1956). The follow- 
ing data are worth recording because of the possibility of establishment of the species where now known and their possible appearance in future years in extreme southeastern Saskatchewan along the Souris River. Since the species is limited in its distribution to areas with oak trees (Quercus sp.) which occur there only sparingly, it is not likely ever to become common in this province.

On August 31, $1957 \mathrm{Mr}$. Edgar Bookhammer turned over to A. E. Swanston, museum assistant, a live male Gray Squirrel captured on the same day at the Bookhammer farm home near Strasbourg, Sask., about one-half mile from Last Mountain Lake. The squirrel had suddenly appeared in the yard and was trapped with the aid of a dog. The species had never before been saen by the Bookhammers and they were anxious to cbtain an identification. The animal was later sacrificed and prepared as a' study specimen for the scientific collections of the Museum. On September 20, 1957 Mr. Bookhammer phoned the museum, reporting the capture and later release of another Gray Squirrel in his yard. He added that a close neighbor, Mr. H. E. Barber, had news of several Gray Squirrels. Accordingly, Fred Lahrman, museum assistant, visited the Barber residence on September 24 and obtained some further information. Gray Squirrels were first observed by Mr. Barber in the fall of 1956 when two appeared in his shelter-belt grove of trees. During the summer of 1957 as many as nine squirrels, two of which drowned in a rain barrel, were observed by the Barber family. According to Mr. Barber, although these squirrels regularly came near the house to feed on grain which was deliberately set out for them, they were never really tamed and were usually difficult to locate in the trees. The squirrels also obtained grain from feeding trays erected for them at a nearby Bible Camp. It was assumed by Mr. Barber that this grain was their main food. Four squirrel nests were observed by Lahrman; all were bulky, leafy-twig nests about the size of a crow's nest and were situated high in the topmost branches of willow and poplar trees. As is usually the case in Gray Squirrel nests, the leafy twigs comprising the nests had been cut while green; the leaves would thus remain permanently attached to the twigs and the nest.

The shelterbelt on the Barber farm is fairly extensive and densely wooded. It contains some very tall Russiar. poplars, willows, maples, ash, elm: and caragana. Undoubtedly the squirrels obtained food from the fruits o some of these trees. The general are on the east side of Last Mountair Lake where these squirrels were found is rather open country; the farm shelterbelts in this vicinity of fer the maximum amount of covel and habitat for Gray Squirrels, although completely lacking any mas or nut trees. The Bookhammer home which is about a mile from Barbers' is treeless. It would seem that the two squirrels which appeared ther had been forced to leave the Barbel woods-possibly as a result of socia pressure because Gray Squirrels, like most mammals, require a certain ex. tent of home range or territory. Or the other hand, since the first squirre captured by Mr. Bookhammer was ar adult male, the squirrels may simpl. have been making exploratory ex. cursions. This species of tree squir rel has been known to make exten. sive movements across country, ever swimming across rivers, usually a the outcome of an increase in popula. tion or a decrease in the food supply During Lahrman's visit no squirrel were observed although considerabl effort was made to locate them. Mr Barber stated at that time that non: had been seen during the previou two weeks.

Evidently the increase in popula tion observed by Mr. Barber indicate actual breeding, probably two o more litters having been produced The number of nests as well as known den in a woodpecker cavit. in a tree support this conclusion There is, however, the possibilit. that several squirrels were intro duced. It seems likely that at leas one pair of Gray Squirrels was re leased near the Barber residence it 1956 or carlier, possibly at the Bibl Camp which attracts a great man: visitors each summer. Owing to th limited wooded area in this vicinit it is unlikely that the Gray Squirre will become permanently establisher as a result of this presumed intro duction. They have been successfull. introduced into British Columbi 
